\title{
COTTON IRRIGATION SCHEDULING IN CENTRAL ASIA: MODEL CALIBRATION AND VALIDATION WITH CONSIDERATION OF GROUNDWATER CONTRIBUTION ${ }^{\dagger}$
}

\author{
E. D. CHOLPANKULOV ${ }^{1}$, O. P. INCHENKOVA ${ }^{1}$, P. PAREDES ${ }^{2}$ AND L. S. PEREIRA ${ }^{2 *}$ \\ ${ }^{I}$ Scientific Information Centre of the Interstate Coordination Water Commission of Central Asia (SIC-ICWC), \\ Tashkent, Uzbekistan \\ ${ }^{2}$ Centre of Agricultural Engineering Research, Institute of Agronomy, Lisbon, Portugal
}

\begin{abstract}
The calibration and validation of the irrigation scheduling simulation model ISAREG for Central Asian conditions were performed using cotton field observations in the Hunger Steppe over the period 1983-87, and in the Fergana Valley for 2001-03. The calibration referred to the crop coefficients and the soil water depletion factor for no stress. Groundwater contribution was considered in computations adopting a set of parametric equations used in ISAREG. Calibration and validation were performed by comparing the observed and simulated soil water content during each crop season. Various indicators of goodness of fit were used to assess model validation. For the Hunger Steppe, the validation also included the comparison of model-computed and field-measured crop evapotranspiration, which was performed with the energy balance method. Results obtained show a good agreement between field observations and model predictions, thus allowing use of the ISAREG model to generate and assess alternative irrigation schedules aimed at improved water use in Central Asia. Copyright (C) 2008 John Wiley \& Sons, Ltd.
\end{abstract}

KEY WORDS: cotton; crop coefficients; crop evapotranspiration; irrigation scheduling; model validation; Central Asia

Received 16 April 2007; Revised 7 December 2007; Accepted 10 December 2007

\section{RÉSUMÉ}

La calibration et la validation du modèle ISAREG pour la simulation du bilan hydrique en vue de la programmation des arrosages du coton a été conduite en Asie Centrale en utilisant des observations de terrain dans la Steppe de la Faim pour la période 1983-87, et dans la Vallée de Ferghana pour 2001-03. La calibration concerne le coefficient cultural et le facteur de réduction de l'eau dans le sol sans stress hydrique. La remontée capillaire a été considérée en adoptant des équations paramétriques utilisées dans ISAREG. La calibration et la validation ont été effectuées en comparant la teneur en eau du sol observée et simulée pendant chaque saison culturale. On a employé plusieurs indicateurs de la qualité et précision des simulations. Pour la Steppe de la Faim, la validation a également inclus la comparaison entre l'évapotranspiration simulée et celle mesurée au champ avec la méthode de bilan énergétique. Les résultats obtenus montrent une bonne concordance entre les observations au champ et les simulations par le modèle, ce qui permet l'utilisation du modèle ISAREG pour produire et évaluer des programmes de conduite des arrosages en vue de l'amélioration de l'utilisation de l'eau en Asie Centrale. Copyright (C) 2008 John Wiley \& Sons, Ltd.

MOTS CLÉS: coton; coefficients culturaux; évapotranspiration culturale; conduite des arrosages; validation d'un modèle; Asie Centrale

\footnotetext{
* Correspondence to: Prof. Dr L. S. Pereira, Centre of Agricultural Engineering Research, Institute of Agronomy, Tapada da Ajuda, 1349-017 Lisbon, Portugal. E-mail: 1spereira@isa.utl.pt

${ }^{\dagger}$ Conduite de l'irrigation du coton en Asie Centrale: Calibration et validation d’un modèle de simulation considérant la remontée capillaire.
} 


\section{INTRODUCTION}

Cotton is the main irrigated crop in large areas of the Aral Sea basin, namely in the Hunger Steppe and Fergana Valley, Uzbekistan. Furrow irrigation is the dominant practice. The Aral Sea basin is widely known as a water-scarce region due to aridity, drought and man-made desertification, the latter related to large-scale projects involving deliberate reshaping of the natural environment (Downing and Lüdeke, 2002). Solving the problem of water scarcity in the area encounters problems of very different nature, and includes several issues in water and salts management at various temporal and spatial scales (Dukhovny and Sokolov, 1998; Dukhovny, 2003; Dukhovny et al., 2005). Coping with these water scarcity regimes requires identification of proper measures and practices, including irrigation water-saving practices (Pereira et al., 2002, 2005).

Recent studies with this objective refer to improving cotton furrow irrigation aimed at water savings and higher water productivity (Horst et al., 2005, 2007). These studies clearly identified the need to better adjust irrigation timings because traditional irrigation results in small soil moisture deficits at time of irrigation that lead to high percolation and runoff volumes. Thus, in addition to improving furrow irrigation systems, there is a need to establish adequate irrigation scheduling for furrow-irrigated cotton.

Cotton irrigation scheduling has been the object of numerous studies (e.g. Yazar et al., 2002; Howell et al., 2004; Karam et al., 2006). Past research in the region aimed at developing appropriate farm irrigation management (e.g. Shreder et al., 1977; Laktaev, 1978; Domullodjanov, 1983) and allow us to base updated modelling issues upon former field studies such as those performed in the Hunger Steppe by Cholpankulov et al. (1984, 1986, 1991, 1992). Thus, past research results were used together with recent ones to calibrate and validate an irrigation scheduling simulation model that could later be explored for establishing irrigation scheduling advice for farmers. Many scientific and technological developments have occurred during the last decade, including those relative to information technologies, which call for the development of a methodological approach that may be used in Central Asia to assess crop and irrigation water requirements and to generate irrigation schedules that provide for improved water use. The ISAREG model (Teixeira and Pereira, 1992; Liu et al., 1998) was selected with this purpose because it proved appropriate for formulating irrigation scheduling studies in several parts of the world and for a variety of crops using simple soil, crop and weather data.

The objectives of the study reported herein are to evaluate past cotton experiment data obtained in the Hunger Steppe and to use them, together with recent data from the Fergana Valley, Uzbekistan, to calibrate and validate the ISAREG model and therefore to derive crop coefficients and depletion fractions for no stress for furrow-irrigated cotton, thus to provide tools for further develop irrigation management alternatives for farming practice.

\section{MATERIALS AND METHODS}

\section{The irrigation scheduling simulation model ISAREG}

The ISAREG model is an irrigation scheduling simulation model that performs soil water balance at field level and simulates alternative irrigation schedules (Teixeira and Pereira, 1992; Liu et al., 1998). Input data include precipitation, reference evapotranspiration, total and readily available soil water, soil water content at planting, potential groundwater contribution, crop coefficients and soil water depletion fractions for no-stress relative to defined crop growth stages, root depths and the water-yield response factor. The water balance is performed for various time-step computations depending on weather data availability. The model is used for a variety of crops and environments, e.g. in the Mediterranean region (Oweis et al., 2003; Zairi et al., 2003), North China (Liu et al., 1998; 2006), South America (Victoria et al., 2005), and Europe (Cancela et al., 2006).

The model computes the potential crop evapotranspiration $\mathrm{ET}_{\mathrm{c}}=K_{\mathrm{c}} \mathrm{ET}_{\mathrm{o}}$ from the reference evapotranspiration $\left(\mathrm{ET}_{\mathrm{o}}, \mathrm{mm}\right)$ and the crop coefficients $\left(K_{\mathrm{c}}\right)$. The actual evapotranspiration $\left(\mathrm{ET}_{\mathrm{a}}, \mathrm{mm}\right)$ is computed by the model as a function of the available soil water in the root zone: $\mathrm{ET}_{\mathrm{a}}=\mathrm{ET}_{\mathrm{c}}$ when depletion is smaller than the depletion fraction for no stress $(p)$, otherwise $\mathrm{ET}_{\mathrm{a}}<\mathrm{ET}_{\mathrm{c}}$ and decreases as a function of the available water stored in the root zone. Both parameters $K_{\mathrm{c}}$ and $p$ should therefore be calibrated together when the model is tested by comparing computed and observed soil water content values. 
The model performs irrigation scheduling simulations according to user-defined options such as:

- to define an irrigation scheduling to maximize crop yields, i.e. without crop water stress;

- to generate an irrigation scheduling using selected irrigation thresholds, including for allowed water stress and responding to water restrictions imposed at given time periods;

- to evaluate yield and water use impacts of a given irrigation schedule;

- to test the model performance against observed soil water data and using actual irrigation dates and depths, which is the option used for calibration and validation;

- to execute the water balance without irrigation; and

- to compute the net crop irrigation requirements, and performing the frequencies' analysis of irrigation requirements when a weather data series is considered.

The Windows version of the model used in this study, WINISAREG (Pereira et al., 2003), includes programs for $\mathrm{ET}_{\mathrm{o}}$ computation and crop parameterization following the FAO methodology described by Allen et al. (1998). It also includes an algorithm to consider soil salinity impacts on $\mathrm{ET}_{\mathrm{c}}$ and yield (Pereira et al., 2007) and parametric functions for computation of the groundwater contribution and percolation (Liu et al., 2006). The water stress impacts on crop yields are evaluated by estimating the relative yield losses as a function of the relative evapotranspiration deficit through the water-yield response factor $K_{\mathrm{y}}$ (Stewart et al., 1977). The model input data includes:

- meteorological data concerning precipitation, $P(\mathrm{~mm})$ and reference evapotranspiration, $\mathrm{ET}_{\mathrm{o}}(\mathrm{mm})$, or weather data to compute $\mathrm{ET}_{\mathrm{o}}$ with the FAO-PM methodology, including alternative computation methods for missing climate data (Allen et al., 1998);

- crop data referring to dates of crop development stages, crop coefficients $\left(K_{\mathrm{c}}\right)$; root zone depths $Z_{\mathrm{r}}(\mathrm{m})$; soil water depletion fractions for no-stress $(p)$; and the seasonal water-yield response factor $\left(K_{\mathrm{y}}\right)$;

- soil data for a multi-layer soil relative to each layer, the respective depth $d(\mathrm{~m})$; the soil water content at field capacity $\theta_{\mathrm{FC}}\left(\mathrm{mm} \mathrm{mm}^{-1}\right)$ and the wilting point $\theta_{\mathrm{WP}}\left(\mathrm{mm} \mathrm{mm}^{-1}\right)$, or the total available water (TAW, $\left.\mathrm{mm}\right)$; an additional file is used to parameterize the equations relative to groundwater contribution and percolation; the initial soil water content is provided by the user.

The equations used to compute the groundwater contribution $G\left(\mathrm{~mm} \mathrm{~d}^{-1}\right)$ from the water table and percolation rates across the root zone bottom $\left(\mathrm{mm} \mathrm{d}^{-1}\right)$ are summarized in Table I. Their application requires that groundwater depths and crop leaf area indices (LAI) are known at various dates during the crop season, and that parameters of the equations are selected according to the soil water characteristics as proposed by Liu et al. (2006). The parameters used are presented in the sections relative to the applications described herein.

\section{Field experiments: the Hunger Steppe case study}

Several field and computer studies were performed to adapt the models for Central Asian conditions, including for estimating the groundwater contribution. Observations formerly performed for cotton in the state farm "Fergana", Hunger Steppe, Syrdarya oblast, Uzbekistan, for 1983-85 and 1987 (Cholpankulov et al., 1984, 1986, 1991, 1992) were used to calibrate and validate the ISAREG model for those conditions, and for the derivation of the crop coefficients and depletion fractions for no stress to be used in further studies. The calibration and validation methodology follows that described by Popova et al. (2006).

The Hunger Steppe is located on the left bank of the SyrDarya river and occupies the largest part of a vast depression limited by the Turkestan ridge in the south, the Nuratau ridge in the south-west and the Kurama and the Chatkal ridge in the east. The western boundary runs along the Aydar Kul Lake, and the northern along the Chardara 
Table I. Parametric equations used to compute the groundwater contribution and percolation fluxes with ISAREG model (Liu et al., 2006)

\begin{tabular}{|c|c|c|}
\hline Equations $^{(*)}$ & Conditions & Parameters \\
\hline \multicolumn{3}{|c|}{ Groundwater contribution } \\
\hline$W_{\mathrm{c}}=a_{1} \cdot D_{\mathrm{w}}^{b l}$ & & $\begin{array}{l}a_{1}=W_{\mathrm{FC}}, \text { the soil water storage to } 1.0 \mathrm{~m} \text { depth at field capacity } \\
b_{1}=-0.17\end{array}$ \\
\hline$W_{\mathrm{s}}=a_{2} \cdot D_{\mathrm{w}}^{b 2}$ & & $\begin{array}{l}a_{2}=1.1\left(W_{\mathrm{FC}}+W_{\mathrm{WP}}\right) / 2 \text {, i.e. a storage above the average } \\
\text { between those at field capacity and the wilting point } \\
b_{2}=-0.27\end{array}$ \\
\hline$D_{\mathrm{wc}}=a_{3} \cdot \mathrm{ET}_{\mathrm{m}}+b_{3}$ & When $\mathrm{ET}_{\mathrm{m}} \leq 4 \mathrm{~mm} \mathrm{~d}^{-1}$ & $a_{3}=-1.3$ \\
\hline$D_{\mathrm{wc}}=1.4$ & When $\mathrm{ET}_{\mathrm{m}}>4 \mathrm{~mm} \mathrm{~d}^{-1}$ & $\begin{array}{l}b_{3}=6.7 \text { for clay and silty clay loam soils, decreasing } \\
\text { to } 6.2 \text { for loamy sands }\end{array}$ \\
\hline$G_{\max }=k \cdot \mathrm{ET}_{\mathrm{m}}$ & When $D_{\mathrm{w}} \leq D_{\mathrm{wc}}$ & $\begin{array}{l}a_{4}=4.6 \text { for silty loam and silty clay loam soils, } \\
\text { decreasing to } 3 \text { for loamy sands }\end{array}$ \\
\hline$G_{\max }=a_{4} \cdot D_{\mathrm{w}}{ }^{b 4}$ & When $D_{\mathrm{w}}>D_{\mathrm{wc}}$ & $\begin{array}{l}b_{4}=-0.65 \text { for silty loam soils and decreasing } \\
\text { to }-2.5 \text { for loamy sand soils }\end{array}$ \\
\hline $\begin{array}{l}k=1-\mathrm{e}^{-0.6} \\
k=38 / \mathrm{ET}_{\mathrm{m}}\end{array}$ & $\begin{array}{l}\text { When } \mathrm{ET}_{\mathrm{m}} \leq 4 \mathrm{~mm} \mathrm{~d}^{-1} \\
\text { When } \mathrm{ET}_{\mathrm{m}}>4 \mathrm{~mm} \mathrm{~d}^{-1}\end{array}$ & \\
\hline \multicolumn{3}{|l|}{ Percolation } \\
\hline$W=a \cdot t^{b}$ & When $W>W_{\mathrm{FC}}$ & $\begin{array}{l}a-\text { a water storage value between } W_{\mathrm{FC}} \text { and } W \text { at saturation } \\
b<-0.0173 \text { for soils draining quickly, otherwise } b>-0.0173\end{array}$ \\
\hline
\end{tabular}

\begin{abstract}
${ }^{(*)}$ Symbols represent the following:
$W=$ soil water storage in the root zone $(\mathrm{mm}), W_{\mathrm{c}}=$ critical soil water storage $(\mathrm{mm}), W_{\mathrm{s}}=$ steady soil water storage $(\mathrm{mm}), W_{\mathrm{FC}}=$ soil water storage at field capacity $(\mathrm{mm}), W_{\mathrm{WP}}=$ soil water storage at wilting point $(\mathrm{mm}), D_{\mathrm{w}}=$ groundwater depth $(\mathrm{m}), D_{\mathrm{wc}}=$ critical groundwater depth $(\mathrm{m}), \mathrm{ET}_{\mathrm{m}}=$ potential crop evapotranspiration rates $\left(\mathrm{mm} \mathrm{d}^{-1}\right)$, usually $\mathrm{ET}_{\mathrm{m}}=\mathrm{ET}_{\mathrm{c}}, G_{\mathrm{max}}=$ potential capillary flux $\left(\mathrm{mm} \mathrm{d}^{-1}\right), k=$ factor relating evapotranspiration with transpiration (non-dimensional), LAI = leaf area index (non-dimensional), $t=$ the time after irrigation or rain has stopped (days).
\end{abstract}

reservoir and the Kyzylkum desert. The SyrDarya River limits the Hunger Steppe in the east and north-east (Figure 1). The experimental area was located in the "Fergana" state farm, Syrdarya oblast.

The weather data were observed at the "Syrdarya" meteorological station $\left(40.2^{\circ} \mathrm{N}, 68.6^{\circ} \mathrm{E}\right.$, and $332 \mathrm{~m}$ elevation). Daily data included temperature, solar radiation, relative humidity and wind speed observed at $2 \mathrm{~m}$ height. High temperatures and low cloudiness characterize the arid continental climate of the region in the summer;

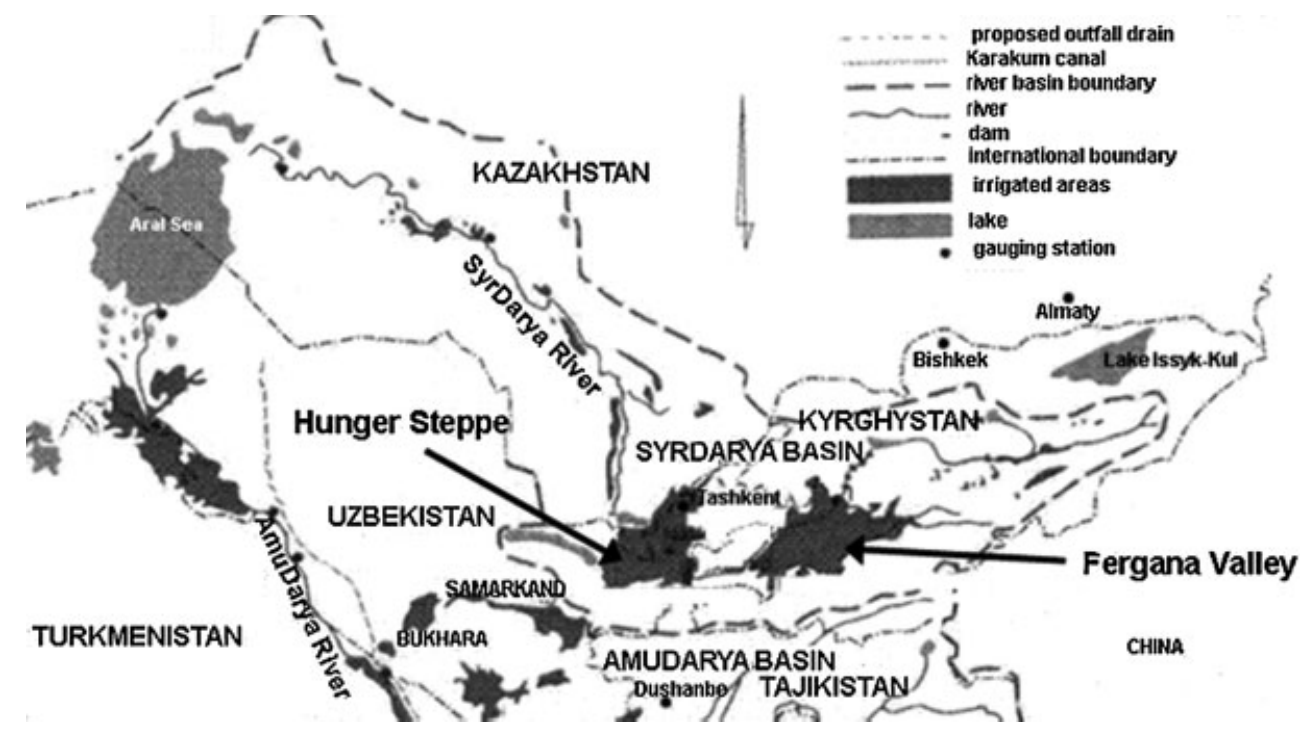

Figure 1. The Aral Sea basin and location of Hunger Steppe and Fergana Valley 
winter temperatures are low. The maximum temperature occurs in July and the minimum in December-January. Precipitation occurs mainly during the winter season and annually varies within $250-300 \mathrm{~mm}$; however, it may reach $430 \mathrm{~mm}$ in locations close to the mountains. The climatic characterization for the cotton crop season (April-September) for the period 1983-87 is presented in Figure 2.

The main soils in the Hunger Steppe are sandy-loam and clay-loam. The unsaturated soil hydraulic proprieties were averaged to the soil depth relative to soil water observations, and are shown in Table II relative to the different experimental plots used each year. These data were obtained using laboratory methods for the full range of soil water tension. Taking into consideration the soil hydraulic properties of the Hunger Steppe soils, the values considered for the groundwater contribution parameters listed in Table I are the following: $a_{1}=320 \mathrm{~mm}$; $b_{1}=-0.17 ; a_{2}=242 \mathrm{~mm} ; b_{2}=-0.27 ; a_{3}=-1.3 ; b_{3}=6.2 ; a_{4}=4 ; b_{4}=-0.65$, and those to parameterize the percolation equation (Table I) are $a=370 \mathrm{~mm}$ and $b=-0.01$.

Observations of the soil moisture were performed down to the water table depth using the gravimetric method. These were made once per 10-day period with at least 2 replications each $20 \mathrm{~cm}$ layer down to $1.5 \mathrm{~m}$. The irrigation inflow rates and volumes applied to the experimental fields were measured with a Cipolletti weir.

The groundwater table depths were observed through appropriate observation wells. Data show they varied within 1.2 and $3.2 \mathrm{~m}$ during the cotton-growing season. This variation relates mainly to the number and volumes of

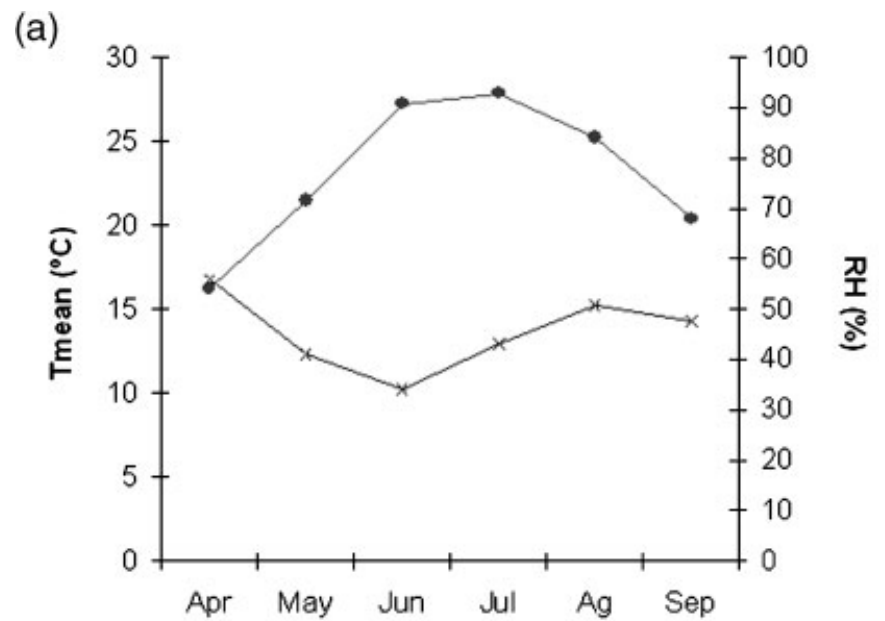

(b)

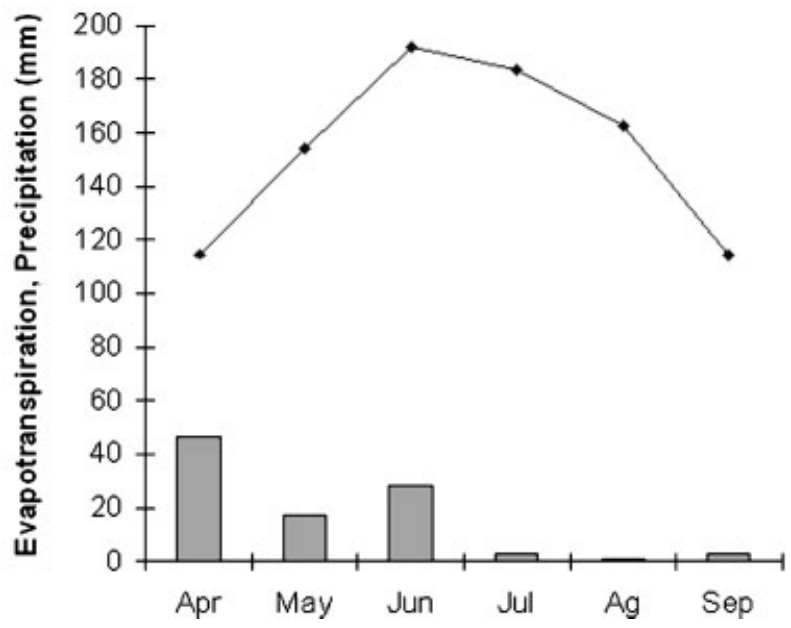

Figure 2. Weather characteristics of the cotton growth season in the Hunger Steppe, 1983-87: (a) average monthly temperature ( - -) and relative humidity $(*)$; and (b) average monthly precipitation $(\square)$ and reference evapotranspiration $\left(\mathrm{ET}_{\mathrm{o}}\right)(\bullet-)$ 
Table II. Field capacity, wilting point and total available water (TAW) of the soils of the Hunger Steppe experimental plots

\begin{tabular}{ccccc}
\hline Year & $\theta_{\mathrm{FC}}\left(\mathrm{m}^{3} \mathrm{~m}^{-3}\right)$ & $\theta_{\mathrm{WP}}\left(\mathrm{m}^{3} \mathrm{~m}^{-3}\right)$ & Soil depth $(\mathrm{m})$ & TAW $(\mathrm{mm})$ \\
\hline 1983 & 0.32 & 0.13 & 1.50 & 285 \\
1984 & 0.32 & 0.11 & 1.50 & 315 \\
1985 & 0.31 & 0.10 & 1.50 & 315 \\
1987 & 0.32 & 0.11 & 1.50 & 315 \\
\hline
\end{tabular}

irrigations practised in the area surrounding the observation plots. Data relative to observed LAI and water table depths used for computing the groundwater contribution are given in Table III for the calibration year, 1983.

The crop evapotranspiration was determined in the Hunger Steppe experiments with the energy balance method as summarized in Appendix 1 (Anon, 1977; Cholpankulov et al., 1992). The radiation balance and the heat flux to the soil were measured with sensors developed at the Leningrad Agrophysical Institute. Observations of temperature, air humidity, and wind speed were performed at 0.5 and $2.0 \mathrm{~m}$ heights.

\section{Field experiments: the Fergana case study}

The Fergana Valley is located in the south-western part of the Tian-Shan mountain system, and is divided among Uzbekistan, Tajikistan and Kyrgyzstan (Figure 1). The valley is bordered by the Fergana ridge in the east, the Alai and Turkestan ridges in the south and the Kurama and Chatkal ridges in the north-west and the north. The Fergana Valley is drained by the SyrDarya River and by numerous mountain streams that are fed by the glaciers in the mountains. The SyrDarya River separates the valley into two parts. The southern one is the largest, where the experimental area, the "Azizbek" farm, near Fergana town, is located.

The weather data were observed at the meteorological station of Fergana $\left(40.77^{\circ} \mathrm{N}, 71.09 \mathrm{E}\right.$, and $439 \mathrm{~m}$ elevation). Daily data include temperature, solar radiation, relative humidity and wind speed observed at $2 \mathrm{~m}$ height, as well as pan evaporation observed with a GGI3000 pan. The climate in the Fergana Valley shows an absolute temperature maximum in July (up to $35^{\circ} \mathrm{C}$ ) and an absolute minimum in January $\left(-14^{\circ} \mathrm{C}\right.$ ). The precipitation ranges within $90-387 \mathrm{~mm}$. The average monthly mean temperature, relative humidity, precipitation and reference evapotranspiration are shown in Figure 3 referring to the period 1970-2003.

The main soils in the Fergana Valley are loamy and clay-loam. The unsaturated soil hydraulic properties characterizing each experimental field were determined from an appropriate survey and using laboratory methods for the full range of soil water tension. Weighed average values referring to the soil depth considered for the simulations are given in Table IV. Considering the soil characteristics, the parameters selected for the equations used for computation of the groundwater contribution and percolation (Table I) are the following: $a_{1}=350 \mathrm{~mm}$; $b_{1}=-0.17 ; a_{2}=250 \mathrm{~mm} ; b_{2}=-0.27 ; a_{3}=-1.3 ; b_{3}=6.6 ; a_{4}=4.6 ; b_{4}=-1.7 ; a=390 \mathrm{~mm}$ and $b=-0.01$.

Observations of the soil water content were performed between irrigation events, as well as before and after irrigations. Measurements were made at 27.5, 42.5, 67.5, 82.5 and $97.5 \mathrm{~cm}$. The gravimetric method was used for the upper soil layer and the neutron probe for the remaining soil depths.

Table III. Water table depths (m) and LAI observed in the experiments for the calibration year, 1983

\begin{tabular}{lcc}
\hline Date & LAI & Water table depth $(\mathrm{m})$ \\
\hline $22-04$ & & 1.7 \\
$09-06$ & 0.21 & 2.3 \\
$22-06$ & 0.45 & 1.5 \\
$06-07$ & 1.54 & 1.8 \\
$21-07$ & 3.14 & 2.1 \\
$04-08$ & 3.50 & 2.0 \\
$21-08$ & 4.10 & 1.9 \\
$14-09$ & 3.30 & 2.6 \\
$30-09$ & 3.00 & 3.2 \\
\hline
\end{tabular}



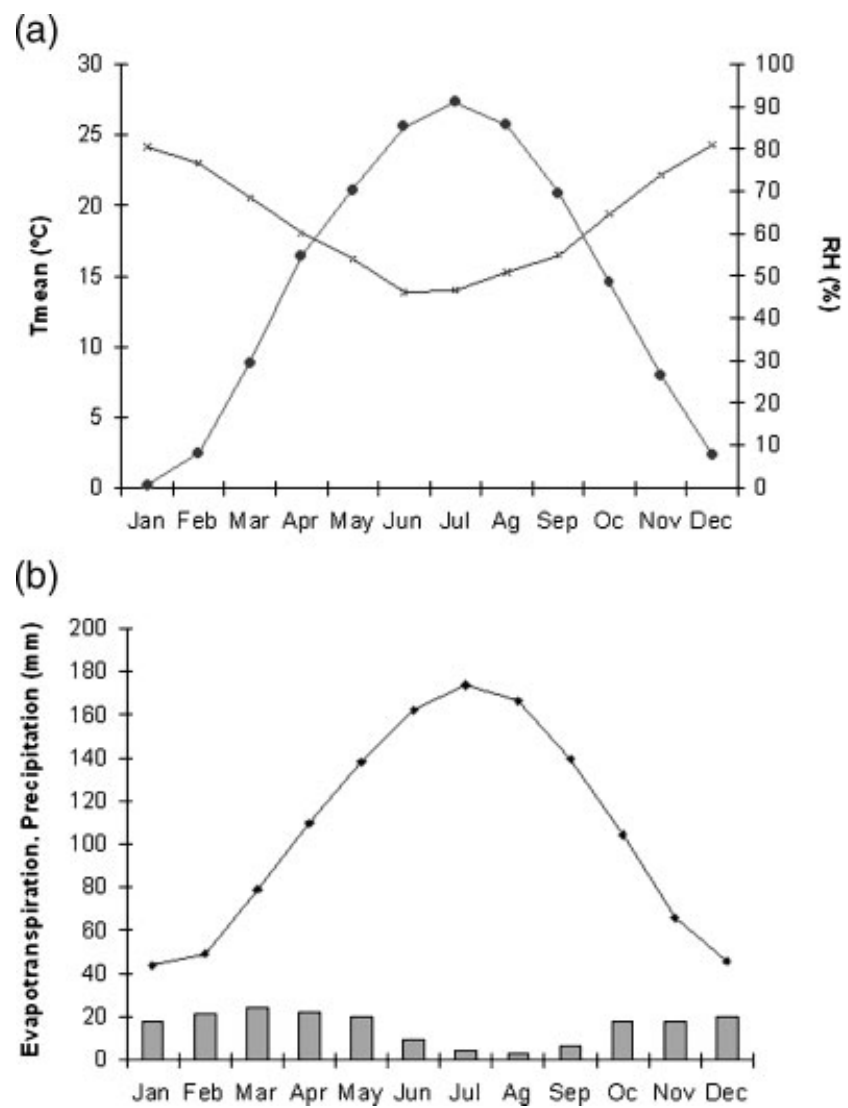

Figure 3. Weather characteristics of Fergana, 1970-2003: a) average monthly temperature (-) and relative humidity ( $\rightarrow$ $)$; and b) average monthly precipitation $(\square)$ and reference evapotranspiration $\left(\mathrm{ET}_{\mathrm{o}}\right)(\rightarrow-)$

To assess the groundwater contribution, observations included the water table depths, which varied between 0.84 and $2.62 \mathrm{~m}$. The water table depth was measured on a weekly basis. Plant development and LAI were observed twice a month for each developmental stage.

\section{Accuracy of computer simulations}

To assess the accuracy of model predictions, several approaches were used. A first one consists in presenting a graphical representation of model-simulated soil water content compared with observed values. This allows a good perception of trends or bias in modelling if they occur. A second one is the regression between observed and model-predicted values forced to the origin. If the regression coefficient $(b)$ is close to 1 then the covariance is close to the variance of the observed values which means that predicted values are statistically close to the observed ones; when the determination coefficient $\left(R^{2}\right)$ is also close to 1.0 , it means that most of the variation of the observed values is explained by the model. In addition, a set of indicators of residual estimation errors is used. An updated review is given by WWRP/WGNE (2007). Indicators are based upon former applications in hydrology (Green and Stephenson, 1986; Loague and Green, 1991; Liu et al., 1998; Legates and McCabe, 1999).

Table IV. Field capacity, wilting point and total available water (TAW) of the soils of the Fergana Valley experimental plots

\begin{tabular}{lcccc}
\hline & $\theta_{\mathrm{FC}}\left(\mathrm{m}^{3} \mathrm{~m}^{-3}\right)$ & $\theta_{\mathrm{WP}}\left(\mathrm{m}^{3} \mathrm{~m}^{-3}\right)$ & Soil depth $(\mathrm{m})$ & TAW $(\mathrm{mm})$ \\
\hline Cotton field no. 1 (2001) & 0.30 & 0.12 & 1.10 & 200 \\
Cotton field no. 2 (2003) & 0.35 & 0.17 & 1.00 & 176 \\
\hline
\end{tabular}


If $O_{i}$ and $P_{i}(i=1,2, \ldots, n)$ are pairs of observed and model-predicted values of a given variable and $\bar{O}$ and $\bar{P}$ are the respective mean values, then the goodness of fit may be assessed through the following indicators:

- the regression and determination coefficients relating observed and simulated data:

$$
\begin{aligned}
& b=\frac{\sum_{i=1}^{n}\left(O_{i}-\bar{O}\right)\left(P_{i}-\bar{P}\right)}{\sum_{i=1}^{n}\left(O_{i}-\bar{O}\right)^{2}} \\
& R^{2}=\left\{\frac{\sum_{i=1}^{n}\left(O_{i}-\bar{O}\right)(P i-\bar{P})}{\left[\sum_{i=1}^{n}\left(O_{i}-\bar{O}\right)^{2}\right]^{0.5}\left[\sum_{i=1}^{n}\left(P_{i}-\bar{P}\right)^{2}\right]^{0.5}}\right\}^{2}
\end{aligned}
$$

- the root mean square error (same units as $O_{i}$ ), which characterizes the variance of the errors:

$$
\mathrm{RMSE}=\left[\frac{\sum_{i=1}^{n}\left(P_{i}-O_{i}\right)^{2}}{n}\right]^{0.5}
$$

- the average absolute error (same units as $O_{i}$ ), which expresses the size of estimation errors as an alternative to RMSE:

$$
\mathrm{AAE}=\frac{1}{n} \sum_{i=1}^{n}\left|O_{i}-P_{i}\right|
$$

- the average relative error $(\%)$, that indicates the size of errors in relative terms:

$$
\mathrm{ARE}=\frac{100}{n} \sum_{i=1}^{n}\left|\frac{O_{i}-P_{i}}{O_{i}}\right|
$$

- the maximum absolute error (same units as $O_{\mathrm{i}}$ ):

$$
E_{\max }=\operatorname{Max}\left|P_{i}-O_{i}\right|_{i=1}^{n}
$$

- the modelling efficiency (non-dimensional), that is the ratio of the mean square error to the variance in the observed data subtracted from unity:

$$
\mathrm{EF}=1.0-\frac{\sum_{i=1}^{n}\left(O_{i}-P_{i}\right)^{2}}{\sum_{i=1}^{n}\left(O_{i}-\bar{O}\right)^{2}}
$$

As referred to by Legates and McCabe (1999), if the square of the differences between the model simulations and the observations is as large as the variability in the observed data, then $\mathrm{EF}=0.0$ and the observed mean, $\bar{O}$, is as good a predictor as the model, while negative values indicate that $\bar{O}$ is a better predictor than the model;

- the index of agreement (non-dimensional)

$$
d_{\mathrm{IA}}=1-\frac{\sum_{i=1}^{N}\left(O_{i}-P_{i}\right)^{2}}{\sum_{i=1}^{N}\left(\left|P_{i}-\bar{O}\right|+\left|O_{i}-\bar{O}\right|\right)^{2}}
$$


Table V. Irrigation scheduling and total irrigation depths ( $\mathrm{mm}$ ) adopted in the field experiments of the Hunger Steppe

\begin{tabular}{llr}
\hline Year & Irrigation dates & Irrigation depths $(\mathrm{mm})$ \\
\hline 1983 & Pre-planting & 140 \\
& 20 Jun & 230 \\
& 22 Jul & 200 \\
& 27 Aug & 200 \\
1984 & Pre-planting & 65 \\
& 18 Jun & 161 \\
& 31 Jul & 250 \\
1985 & 21 Aug & 219 \\
& Pre-planting & 117 \\
1987 & 16 Jul & 310 \\
& Pre-planting & 121 \\
& 14 Jul & 220 \\
& 30 Aug & 180 \\
\hline
\end{tabular}

It corresponds to the ratio between the mean square error and the "potential error", which is defined as the sum of the squared absolute values of the distances from $P_{i}$ and $O_{i}$ to $\bar{O}$, and represents the largest value that can be attained for each observation/model simulation pair (Legates and McCabe, 1999). The maximum value for $d_{\mathrm{IA}}$ is 1.0.

\section{RESULTS AND DISCUSSION}

\section{Hunger Steppe}

The calibration of the ISAREG model refers to field data observed in 1983 and the validation was performed using data of the experiments carried out in 1984, 1985 and 1987. The calibration consisted in searching the $K_{\mathrm{c}}$ and $p$ values that lead to the best fit of the observed soil moisture. These values were later used with the model and data for the validation years. The irrigation schedules adopted in those years are given in Table V. They provide for a wide spectrum of irrigation scheduling options and for a wide range of soil water conditions.

The crop parameters obtained from the calibration are presented in Table VI together with the dates of the crop growth stages in the four years under analysis. The $K_{\mathrm{c} \text { ini }}$ values are relatively high because a large irrigation was applied before planting to create appropriate conditions for plant establishment and development. The $K_{\mathrm{c} \text { mid }}$ are similar to those recommended by Allen et al. (1998), while $K_{\mathrm{c}}$ end are lower than those recommended by these authors. The depletion fractions $p$ are generally higher than those proposed by Allen et al. (1998), and they relate to the cotton varieties used, which were developed with the aim of controlling the development of above-ground biomass and favouring harvestable yield.

Table VI. Calibrated cotton crop coefficients $\left(K_{\mathrm{c}}\right)$ and depletion fractions for no stress $(p)$, and dates of crop growth stages for the calibration and validation experiments, Hunger Steppe

\begin{tabular}{|c|c|c|c|c|}
\hline & \multicolumn{4}{|c|}{ Crop growth stages } \\
\hline & Initial & Development & Mid season & End season \\
\hline \multicolumn{5}{|l|}{ Crop parameters } \\
\hline Crop coefficients, $K_{\mathrm{c}}$ & 0.40 & $0.40-1.20$ & 1.20 & $1.2--0.25$ \\
\hline Depletion fraction, $p$ & 0.60 & $0.60-0.70$ & 0.70 & $0.70-0.75$ \\
\hline \multicolumn{5}{|l|}{ Period length (dates) } \\
\hline 1983 (calibration) & $22 / 04-15 / 06$ & $16 / 06-21 / 07$ & $22 / 07-30 / 08$ & $31 / 08-30 / 09$ \\
\hline 1984 (validation) & $29 / 04-20 / 06$ & $21 / 06-25 / 07$ & $26 / 07-29 / 08$ & $30 / 08-30 / 09$ \\
\hline 1985 (validation) & $22 / 04-10 / 06$ & $11 / 06-20 / 07$ & $21 / 07-25 / 08$ & $25 / 08-30 / 09$ \\
\hline 1987 (validation) & $06 / 05-22 / 06$ & 23/06-22/07 & 22/07-05/09 & 06/09-30/09 \\
\hline
\end{tabular}


Results comparing the simulated with observed soil moisture for the calibration year and for one of the validation years, 1985, are given in Figure 4. Results show a good agreement between observed and computed soil water content, which is confirmed by the parameters used to evaluate the goodness of fit (Table VII). In addition to Figure 4, a regression through the origin relative to observed and computed soil water content for all experiments is presented in Figure 5.

Results in Table VII show that the regression coefficients are close to 1.0 for all experiments in both the calibration and validation, with $R^{2}$ values ranging 0.87 to 0.94 , thus indicating that a large fraction of the variation of observations is explained by the model. The RMSE and AAE are very small, close to $0.01 \mathrm{~m}^{3} \mathrm{~m}^{-3}$, and the maximum error was $0.01 \mathrm{~m}^{3} \mathrm{~m}^{-3}$ for the calibration and close to $0.03 \mathrm{~m}^{3} \mathrm{~m}^{-3}$ for the validation. ARE ranged from 2 to $6 \%$. The efficiency and agreement indices, $\mathrm{EF}$ and $d_{\mathrm{IA}}$, have values near 1.0 except for 1984 , when $\mathrm{EF}=0.79$. When considering all 4 years' data together (Figure 5), indicators improve due to sample size, e.g. EF and $d_{\mathrm{IA}}$ are then 0.93 and 0.98 respectively. All indicators express the ability of the model to predict soil water content for a furrow-irrigated cotton crop.

In addition, because field-observed cotton ET values are available, a comparison between observed and model-computed monthly ET and seasonal ET was also performed, as shown in Figure 6 and Table VIII, respectively. Results comparing monthly ET values show a good agreement between simulated and observed values, with a regression coefficient very close to 1.0 and a high coefficient of determination $(0.82)$. The values

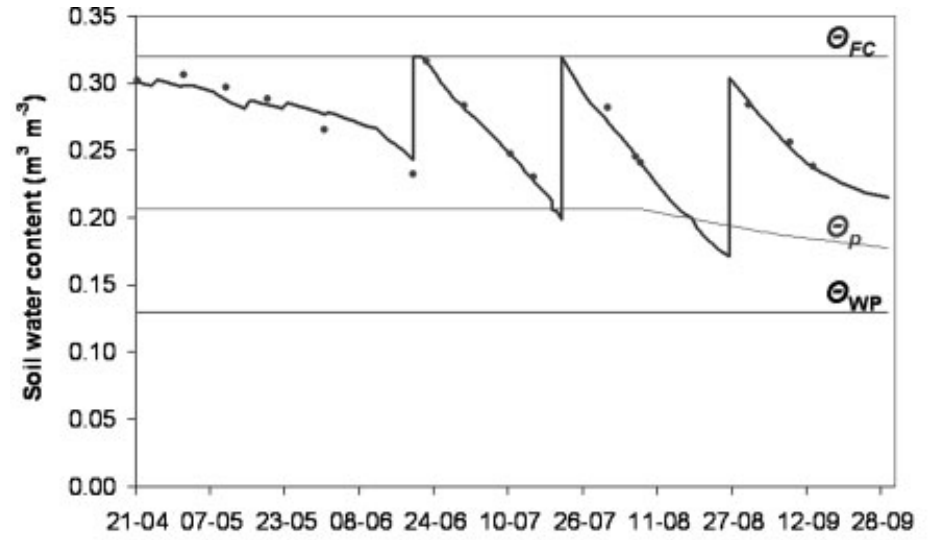

(a)

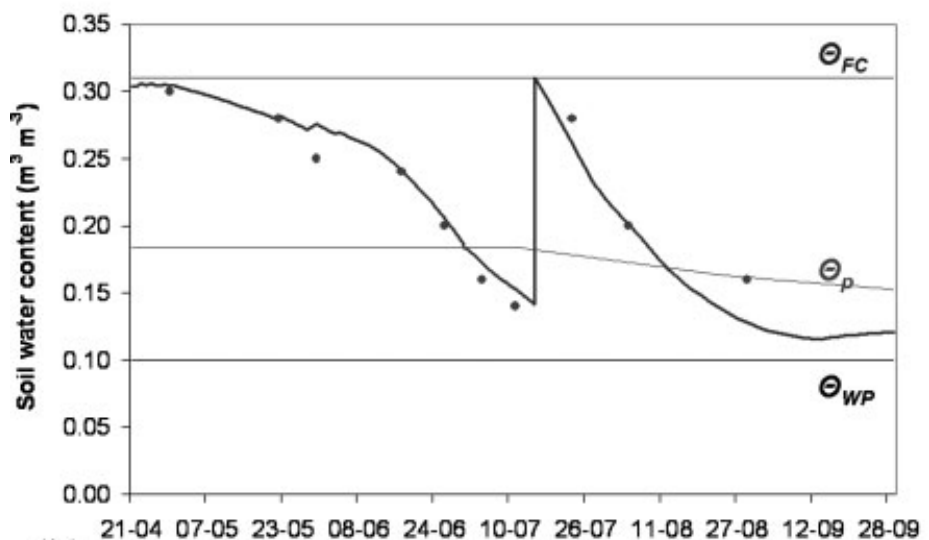

(b)
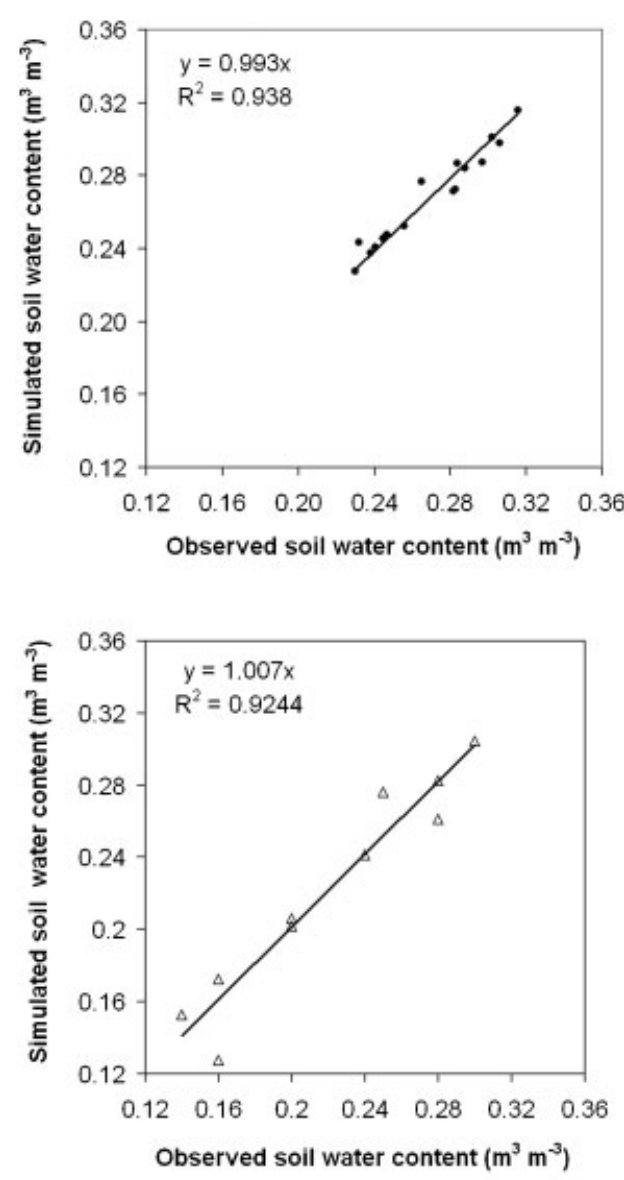

Figure 4. Comparison between simulated and observed soil water content for the cotton crop in the Hunger Steppe: on the left, the simulated soil water content curves and observed values $(\bullet)$ (curves $\theta_{\mathrm{FC}}, \theta_{\mathrm{WP}}$ and $\theta_{p}$ represent soil moisture at field capacity, wilting point, and when depletion equals the fraction $p$, respectively); on the right the regressions between observed and simulated soil water content for: (a) 1983 (calibration), and (b) 1985 (validation) 
Table VII. Indicators of goodness of fit relative to model calibration and validation, Hunger Steppe

\begin{tabular}{lccccccrr}
\hline & $b$ & $R^{2}$ & $\operatorname{RMSE}\left(\mathrm{m}^{3} \mathrm{~m}^{-3}\right)$ & $\operatorname{AAE}\left(\mathrm{m}^{3} \mathrm{~m}^{-3}\right)$ & $\operatorname{ARE}(\%)$ & $E_{\max }\left(\mathrm{m}^{3} \mathrm{~m}^{-3}\right)$ & $\mathrm{EF}$ & $d_{\mathrm{IA}}$ \\
\hline $\begin{array}{l}\text { Calibration } \\
\quad \begin{array}{l}\text { 1983 } \\
\text { Validation }\end{array}\end{array}$ & 0.99 & 0.94 & 0.01 & 0.005 & 1.81 & 0.012 & 0.94 & 1.00 \\
1984 & & & & & & & & \\
1985 & 0.998 & 0.87 & 0.01 & 0.010 & 4.18 & 0.032 & 0.79 & 0.96 \\
$\quad 1987$ & 1.01 & 0.93 & 0.02 & 0.011 & 6.08 & 0.030 & 0.92 & 0.98 \\
All experiments & 1.02 & 0.93 & 0.01 & 0.001 & 4.84 & 0.027 & 0.96 & 0.99 \\
& 1.00 & 0.93 & 0.01 & 0.004 & 3.93 & 0.032 & 0.93 & 0.98 \\
\hline
\end{tabular}

All symbols are defined in Equations (1)-(8).

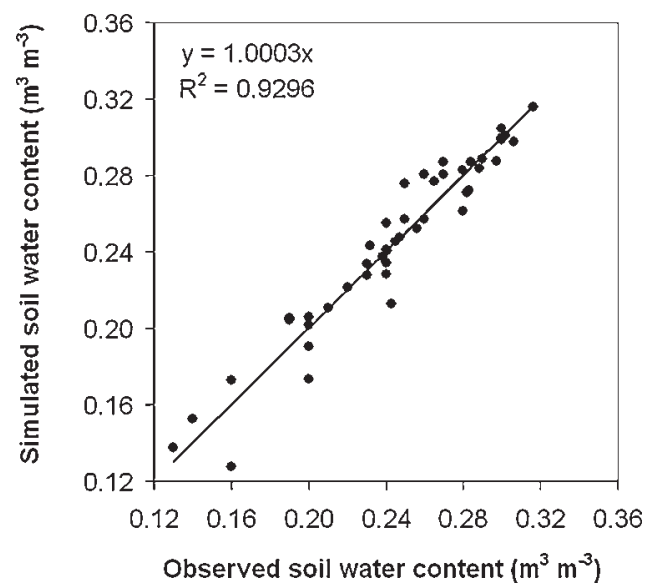

Figure 5. Comparison between observed and simulated soil water content, Hunger Steppe, 1983, 1984, 1985 and 1987

$\mathrm{AAE}=15.4 \mathrm{~mm} \mathrm{month}^{-1}, \mathrm{EF}=0.70$ and $d_{\mathrm{IA}}=0.94$ confirm the good agreement between simulated and observed monthly ET values. Observed and simulated seasonal cotton ET (Table VIII) are also shown to be in agreement, with differences ranging from 4 to $7 \%$.

Results indicate that the ISAREG model adequately predicts soil water contents and evapotranspiration of a cotton crop cultivated in the Hunger Steppe, including consideration of groundwater contribution. Thus the model may be used for generating and analysing alternative irrigation schedules for improved water use in the area.

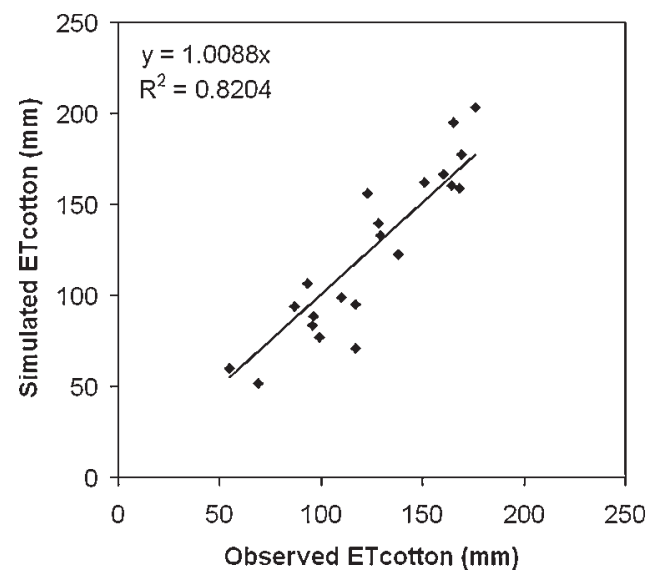

Figure 6. The regression between observed and computed monthly cotton evapotranspiration (Hunger Steppe, 1983, 1984, 1985 and 1987) 
Table VIII. Comparison of measured and simulated seasonal evapotranspiration, Hunger Steppe, 1983-87

\begin{tabular}{lrrrr}
\hline Seasonal ET & 1983 & 1984 & 1985 & 1987 \\
\hline Observed (mm) & 730 & 670 & 685 & 701 \\
Simulated (ISAREG) (mm) & 681 & 637 & 720 & 675 \\
Difference (\%) & 7 & 5 & 5 & 4 \\
\hline
\end{tabular}

Results also show that the calibrated crop coefficients $K_{\mathrm{c}}$ and depletion fractions $p$ (Table VI) may be further adopted for the cotton varieties used in the region. Moreover, the analysis performed shows that using past experimental data for updated modelling is appropriate.

\section{Case study relative to the Fergana Valley}

The reference evapotranspiration, $\mathrm{ET}_{\mathrm{o}}$, was computed with the FAO-PM method (Allen et al., 1998) using daily data for the period 2001-03 in the Fergana Valley. However, few locations in the area have observations of the climatic variables required for that computation (maximum and minimum temperatures, relative humidity, solar radiation or actual sunshine duration and wind speed), but evaporation observations with the GGI-3000 pan are frequent. The pan is located within a short green cover and relatively small fetch, $10-20 \mathrm{~m}$, which is common in the Fergana Valley. Thus, $\mathrm{ET}_{\mathrm{o}}$ (FAO-PM) and observed GGI-3000 pan evaporation data referring to the cotton growth period (April to November) were compared (Figure 7) to derive a pan coefficient $\left(K_{\mathrm{p}}\right)$ adapted to the area. Results show that a pan coefficient $K_{\mathrm{p}}=0.80$ may be used. However, the value obtained for $R^{2}$ indicates that only $79 \%$ of the data variation is explained through the regression, thus leading to errors of estimates $\mathrm{AAE}=1.0 \mathrm{~mm}^{\mathrm{day}}{ }^{-1}$.

The calibration of the ISAREG model for cotton was performed using field data from 2001 and the validation referred to 2003 observed data. Calibration and validation of the model were performed as for the Hunger Steppe case study. Observed data on irrigation are given in Table IX. Different from that case study, the irrigation schedules adopted in the "Azizbek" farm aimed at avoiding crop water stress and followed those adopted by local farmers. Thus, irrigation depths exceed those for Hunger Steppe and were applied when the soil water content was relatively high, not avoiding percolation. The results comparing simulated and observed soil water content data are shown in Figure 8 .

The crop coefficients $\left(K_{\mathrm{c}}\right)$ and the depletion fractions for no stress $(p)$ derived from the calibration and verified through the validation are presented in Table X. Values for both $K_{\mathrm{c}}$ and $p$ are in the range of those recommended by Allen et al. (1998). The $K_{\mathrm{c} \text { mid }}$ are the same as those obtained for the Hunger Steppe, but the $K_{\mathrm{c}}$ end values are much higher because a later irrigation was applied, which may be not required. The $p$ fractions are slightly smaller than

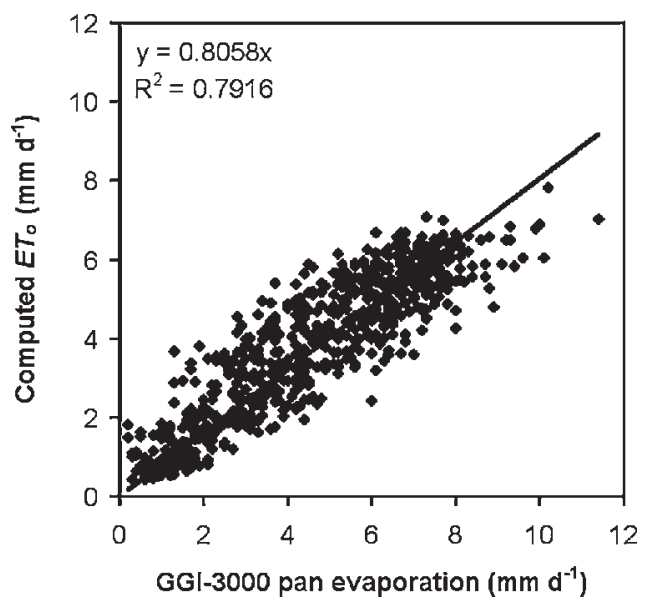

Figure 7. Comparison between observed daily GGI-3000 pan evaporation and computed daily FAO-PM reference evapotranspiration, Fergana Valley (2001-03) 
Table IX. Irrigation scheduling and total irrigation depths, "Azizbek" farm, Fergana Valley

\begin{tabular}{|c|c|c|c|}
\hline Experiment & Dates & Irrigation depths (mm) & Total (mm) \\
\hline \multirow[t]{6}{*}{ 2001, Cotton field no. 1} & 8 Apr $^{*}$ & 143 & \multirow[t]{6}{*}{764} \\
\hline & 2 Jun & 127 & \\
\hline & 25 Jun & 174 & \\
\hline & $11 \mathrm{Jul}$ & 123 & \\
\hline & $25 \mathrm{Jul}$ & 111 & \\
\hline & 7 Aug & 86 & \\
\hline \multirow[t]{7}{*}{ 2003, Cotton field no. 2} & 14 Mar* $^{*}$ & 171 & \multirow[t]{7}{*}{820} \\
\hline & 15 Jun & 125 & \\
\hline & $6 \mathrm{Jul}$ & 103 & \\
\hline & $23 \mathrm{Jul}$ & 123 & \\
\hline & 8 Aug & 114 & \\
\hline & 24 Aug & 91 & \\
\hline & $10 \mathrm{Sep}$ & 93 & \\
\hline
\end{tabular}

${ }^{*}$ Pre-planting irrigation.

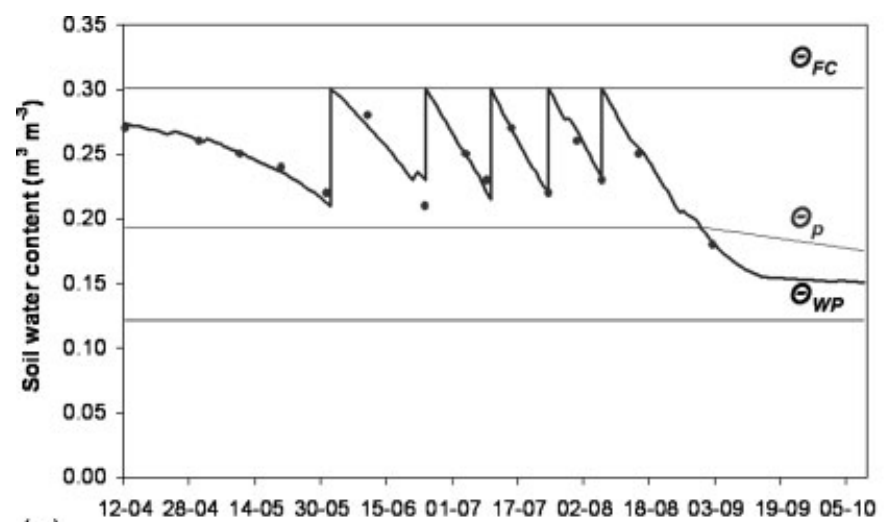

(a)

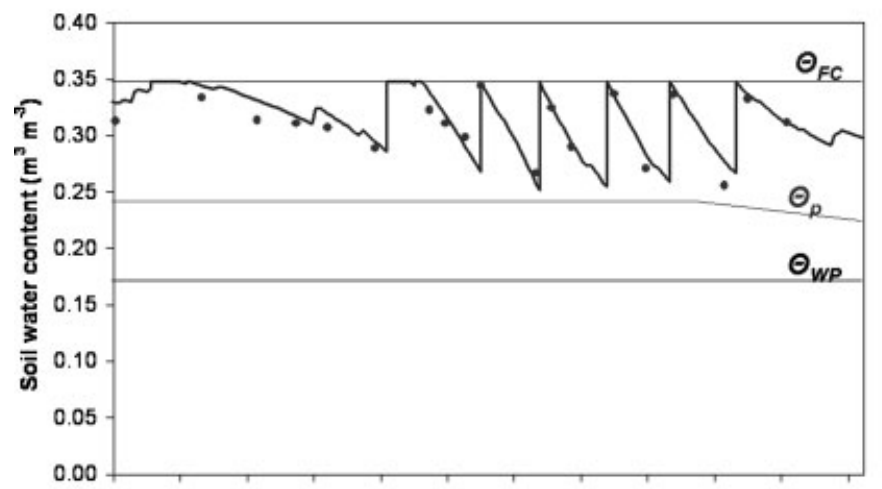

(b)
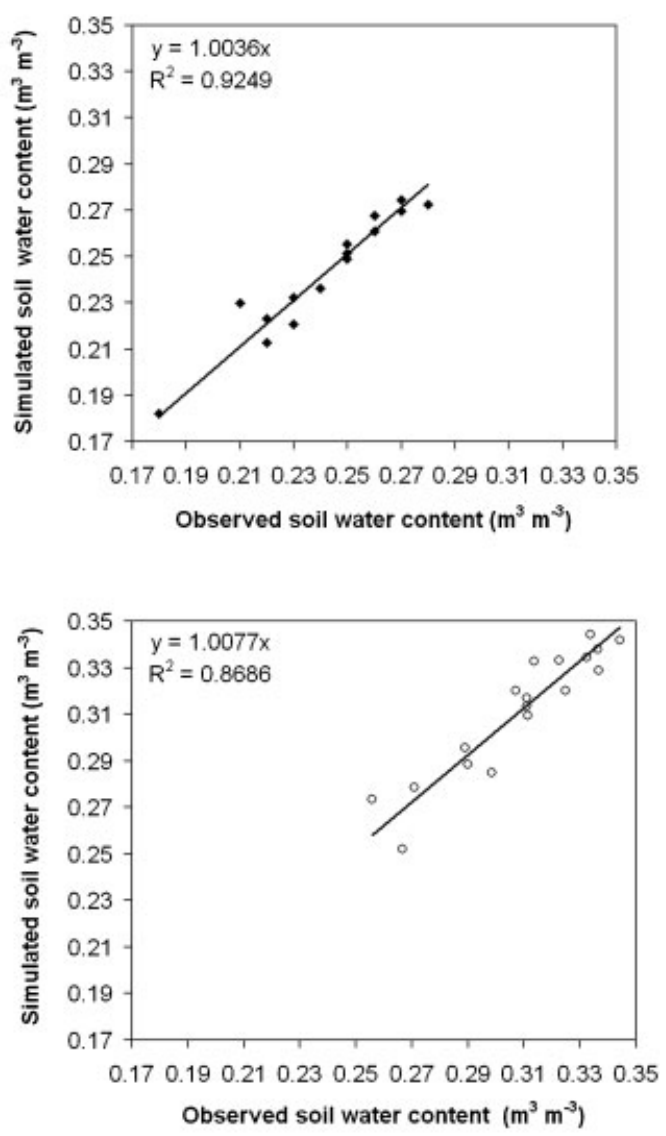

Figure 8. Comparison between observed and simulated soil water content for the cotton crop at the "Azizbek" farm, Fergana Valley. On the left, the simulated soil water content curves and observed values $\left(\bullet\right.$ ) (curves $\theta_{\mathrm{FC}}, \theta_{\mathrm{WP}}$ and $\theta_{p}$ represent soil moisture at field capacity, wilting point, and when depletion equals the fraction $p$, respectively); on the right, the regressions between observed and simulated soil water content for: (a) 2001 (calibration); (b) 2003 (validation) 
Table X. Cotton crop growth stages, crop coefficients $\left(K_{\mathrm{c}}\right)$ and depletion fractions for no stress $(p)$ in Fergana Valley

\begin{tabular}{lcccc}
\hline & \multicolumn{3}{c}{ Crop growth stages } \\
\cline { 2 - 5 } & Initial & Development & Mid season & End season \\
\hline Crop parameters & & & & \\
$\quad$ Crop coefficients, $K_{\mathrm{c}}$ & 0.30 & $0.30-1.20$ & 1.20 & $1.2-0.65$ \\
$\quad \begin{array}{l}\text { Depletion fraction, } p \\
\text { Period length (dates) }\end{array}$ & 0.60 & 0.60 & 0.60 & $0.60-0.70$ \\
$\quad$ 2001 (calibration) & $13 / 4-17 / 05$ & $18 / 05-17 / 07$ & $18 / 07-31 / 08$ & $1 / 09-10 / 10$ \\
2003 (validation) & $6 / 04-20 / 05$ & $21 / 05-19 / 07$ & $20 / 07-1 / 09$ & $2 / 09-14 / 10$ \\
\hline
\end{tabular}

Table XI. Parameters of goodness of fit relative to model calibration and validation, Fergana Valley

\begin{tabular}{|c|c|c|c|c|c|c|c|c|}
\hline & $b$ & $R^{2}$ & $\operatorname{RMSE}\left(\mathrm{m}^{3} \mathrm{~m}^{-3}\right)$ & $\operatorname{AAE}\left(\mathrm{m}^{3} \mathrm{~m}^{-3}\right)$ & $\operatorname{ARE}(\%)$ & $E_{\max }\left(\mathrm{m}^{3} \mathrm{~m}^{-3}\right)$ & $\mathrm{EF}$ & $d_{\mathrm{IA}}$ \\
\hline \multicolumn{9}{|l|}{ Calibration } \\
\hline 2001 & 1.00 & 0.92 & 0.01 & 0.005 & 2.17 & 0.020 & 0.93 & 0.98 \\
\hline \multicolumn{9}{|l|}{ Validation } \\
\hline 2003 & 1.01 & 0.87 & 0.01 & 0.008 & 2.67 & 0.019 & 0.85 & 0.96 \\
\hline
\end{tabular}

All symbols are defined in Equations (1)-(8).

those for the Hunger Steppe, given the irrigation schedules utilized in Fergana. The trend in the area is to adopt a management-allowed depletion (MAD) even smaller than the $p$ value obtained in this study, which often causes high percolation (Horst et al., 2005).

Indicators for goodness of fit relative to both the calibration and validation of the model for Fergana are given in Table XI. They show regression coefficients $b$ very close to 1.0 and $R^{2}$ near to 0.90 , thus indicating that predicted values are close to observed ones. Estimation errors are very low, with RMSE of $0.01 \mathrm{~m}^{3} \mathrm{~m}^{-3}, \mathrm{AAE}<0.01 \mathrm{~m}^{3} \mathrm{~m}^{-3}$, and $E_{\max }<0.02 \mathrm{~m}^{3} \mathrm{~m}^{-3}$. The ARE values are quite small, between 2 and $3 \%$. The indices of efficiency and agreement, $\mathrm{EF}$ and $d_{I \mathrm{~A}}$, are near 1.0, thus indicating that the model is able to appropriately predict the soil water content for furrow-irrigated cotton in the Fergana Valley. These results are similar to those obtained for the Hunger Steppe.

Results for the Fergana Valley show that the crop coefficients $K_{\mathrm{c}}$ and depletion fractions $p$ described in Table X may be further adopted for the cotton varieties used in the region. Simple experiments in the Fergana area have proved that a simple methodology to advise farmers can be used with the model ISAREG when it is explored in successive runs by updating the weather data, thus adjusting predictions to the prevalent weather conditions and crop development. Moreover, using the model with a GIS database is also foreseen since a GIS version of ISAREG has been developed and tested for the Fergana area (Fortes et al., 2005).

\section{CONCLUSIONS}

The ISAREG model was successfully calibrated and validated using past observations of the soil water and cotton evapotranspiration at Syrdarya, Hunger Steppe, for the period 1983-87. The analysis shows that using past experimental data for updated modelling is appropriate and produces valuable information in addition to data obtained through recent experiments. For both the soil water and crop ET, the regression coefficients relating simulated and observed values were close to 1.0 and the determination coefficients were higher than 0.90 . All goodness of fit indicators show good or very good results. Moreover, because these results were obtained using the parametric equations adopted in ISAREG to compute groundwater contribution and percolation, results also show that the model may be explored with consideration of the fluxes through the bottom of the root zone. The studies 
therefore produced good estimates of the crop coefficients and depletion fractions for no stress that may be further used in searching for water- saving irrigation schedules in the Hunger Steppe area.

The model was also calibrated and validated for the cotton crop in the Fergana Valley using experiments that reproduce the irrigation schedules adopted by farmers. As for the Hunger Steppe, results for the analysis of goodness of fit show that the model is appropriately calibrated and validated for further use in the area, including with consideration of the groundwater contribution.

Further developments will concern the development of irrigation scheduling strategies that take into account the constraints of the furrow irrigation systems adopted in the area and provide for improved water use. The calibrated values for $K_{\mathrm{c}}$ and $p$ may be further used to define when to irrigate and the irrigation depths which should satisfy either the crop irrigation requirements without producing excess above-ground biomass, or lead to an allowable water stress that results in limited losses of harvestable yields.

\section{ACKNOWLEDGEMENTS}

The present studies were funded by the EU-INCO project ICA2-CT-2000-10039.

\section{APPENDIX 1}

The simplified equation for the energy balance of a canopy may be written as (Anon., 1977)

$$
E=\mathrm{CF}(R-B-Q)
$$

where $E$ is cumulative evaporation ( $\mathrm{mm}$ ) or latent heat flux, $R$ is radiation balance ( $\mathrm{cal} \mathrm{cm}^{-2}$ ) or net radiation, $B$ is heat flux to the soil $\left(\mathrm{cal} \mathrm{cm}^{-2}\right), Q$ is turbulent heat exchange $\left(\mathrm{cal} \mathrm{cm}^{-2}\right)$ or sensible heat flux, and $\mathrm{CF}$ is the conversion factor relative to units and timescale of observations.

The radiation balance and the heat flux to the soil were measured in the field with sensors developed at the Leningrad Agrophysical Institute. Temperature and air humidity observations were performed at 0.5 and $2.0 \mathrm{~m}$ heights, respectively $T_{0.5}-T_{2.0}$. When $(R-B)>0.2 \mathrm{cal} \mathrm{cm}^{-2} \mathrm{~min}, T \geq 0.3^{\circ} \mathrm{C}\left(T=T_{0.5}-T_{2.0}\right)$ and $e \geq 0.3 \mathrm{mbar}$ $\left(e=e_{0.5}-e_{2.0}\right)$, the turbulent heat exchange is estimated by

$$
Q=\frac{(R-B) T}{(T+1.56 e)}
$$

or, when the above mentioned conditions are not fulfilled, by

$$
Q=1.35 K T
$$

where $K$ is a turbulence coefficient characterizing the intensity of vertical heat transport. $K$ is given by

$$
\begin{aligned}
& K=0.104 m u \quad \text { if } T \geq-2.0^{\circ} \mathrm{C} \text { or } u \geq 0.3 \mathrm{~m} \mathrm{~s}^{-1} \\
& K=0 \quad \text { if } T<-2.0^{\circ} \mathrm{C} \text { or } u<0.3 \mathrm{~m} \mathrm{~s}^{-1}
\end{aligned}
$$

where $u$ is the difference between wind speed $\left(\mathrm{m} \mathrm{s}^{-1}\right)$ observed at 2.0 and $0.5 \mathrm{~m}$ heights, and $m$ is a value depending on the Richardson number $R_{i}$ :

$$
\begin{aligned}
& m=1+2.6 R_{i}+\left(\left(1+2.6 R_{i}\right)^{2}-1\right)^{0.5} \quad \text { if } R_{i} \leq 0 \\
& m=1+10.3 R_{i}-\left(\left(1+10.3 R_{i}\right)^{2}-1\right)^{0.5} \quad \text { if } R_{i}>0
\end{aligned}
$$

with

$$
R_{i}=-0.048 T /(u)^{2}
$$




\section{REFERENCES}

Allen RG, Pereira LS, Raes D, Smith M. 1998. Crop Evapotranspiration. Guidelines for Computing Crop Water Requirements. FAO Irrig.ation and Drainage Paper 56, FAO, Rome, 296 pp.

Anon. 1977. Manual for Heat Balance Observations. Gidrometeroizdat: Leningrad (in Russian).

Cancela JJ, Cuesta TS, Neira XX, Pereira LS. 2006. Modelling for improved irrigation water management in a temperate region of Northern Spain. Biosystems Engineering 94(1): 151-163.

Cholpankulov ED, Milkis BE, Muhamedjanov ShSh. 1984. Operational water consumption management in order to control melioration regimes. In Trudy SANIIRI, vol. 172. SANIIRI: Tashkent; 166-174 (in Russian).

Cholpankulov ED, Baclushin MB, Dudko OP, Duchovny VA. 1986. Prediction of soil water distribution based on hydrometeorological data. In Proceedings, Uzbekistan IZV Academy of Science, vol. 4, Tashkent; $47-49$ (in Russian).

Cholpankulov ED, Baclushin MB, Dudko OP, Duchovny VA. 1991. Calculation of cotton planting dates. In Multiphase Medium and Heat-Mass Exchange Mechanics, series Tech. Nauk. SANIIRI: Tashkent; 32-35 (in Russian).

Cholpankulov ED, Urunov N, Dudko OP. 1992. Estimation of cumulative evaporation from cotton field. Agriculture in Uzbekistan, 4-5, Tashkent; 45-46 (in Russian).

Domullodjanov KhD. 1983. Recommendations for Calculating Irrigation Regimes when Programming Yields in Cotton Rotation in Tajik SST. Dushanbe; 74 pp. (in Russian).

Downing TE, Lüdeke M. 2002. International desertification. Social geographies of vulnerability and adaptation. In Global Desertification: Do Humans Cause Deserts? Reynolds JF, Stafford Smith DM (eds). Dahlem University Press: Berlin; 233-252.

Dukhovny VA. 2003. The Aral Sea Basin - rumors, realities, prospects. Irrigation and Drainage 52(2): 109-120.

Dukhovny VA, Sokolov VI. 1998. Water and salt management strategies in the Aral Sea Basin. In Water and the Environment: Innovation Issues in Irrigation and Drainage, Pereira LS, Gowing JW (eds). E\& FN Spon: London; 416-421.

Dukhovny VA, Yakubov Kh, Umarov PD. 2005. Drainage and salinity control: review of related problems in Central Asia. In Irrigation Management for Combating Desertification in the Aral Sea Basin. Assessment and Tools, Pereira LS, Dukhovny VA, Horst MG (eds). Vita Color Publisher: Tashkent; 247-268.

Fortes PS, Platonov AE, Pereira LS. 2005. GISAREG - a GIS based irrigation scheduling simulation model to support improved water use. Agricultural Water Management 77: 159-179.

Green IR, Stephenson D. 1986. Criteria for comparison of single event models. Hydrology Science Journal 31: 395-411.

Horst MG, Shamutalov ShS, Pereira LS, Gonçalves JM. 2005. Field assessment of the water saving potential with furrow irrigation in Fergana, Aral Sea Basin. Agricultural Water Management 77: 210-231.

Horst MG, Shamutalov ShSh, Gonçalves JM, Pereira LS. 2007. Assessing impacts of surge-flow irrigation on water saving and productivity of cotton. Agricultural Water Management 87(2): 115-127.

Howell TA, Evett SR, Tolk JA, Schneider AD. 2004. Evapotranspiration of full-, deficit-irrigated, and dryland cotton on the northern Texas high plains. Journal of Irrigation and Drainage Engineering 130(4): 277-285.

Karam F, Lahoud R, Masaad R, Daccache A, Mounzer O, Rouphael Y. 2006. Water use and lint yield response of drip irrigated cotton to the length of irrigation season. Agricultural Water Management 85: 287-295.

Laktaev N. 1978. Cotton Irrigation. Kolos Publishers: Moscow (in Russian).

Legates DR, McCabe G. 1999. Evaluating the use of "goodness of fit" measures in hydrologic and hydroclimatic model validation. Water Resources Research 35(1): 233-241.

Liu Y, Teixeira JL, Zhang HJ, Pereira LS. 1998. Model validation and crop coefficients for irrigation scheduling in the North China Plain. Agricultural Water Management 36: 233-246.

Liu Y, Pereira LS, Fernando RM. 2006. Fluxes through the bottom boundary of the root zone in silty soils: parametric approaches to estimate groundwater contribution and percolation. Agricultural Water Management 84: 27-40.

Loague K, Green RF. 1991. Statistical and graphical methods for evaluating solute transport models: overview and application. Journal of Contaminant Hydrology 7: 183-196.

Oweis T, Rodrigues PN, Pereira LS. 2003. Simulation of supplemental irrigation strategies for wheat in Near East to cope with water scarcity. In Tools for Drought Mitigation in Mediterranean Regions, Rossi G, Cancelliere A, Pereira LS, Oweis T, Shatanawi M, Zairi A (eds). Kluwer: Dordrecht; 259-272.

Pereira LS, Oweis T, Zairi A. 2002. Irrigation management under water scarcity. Agricultural Water Management 57: 175-206.

Pereira LS, Teodoro PR, Rodrigues PN, Teixeira JL. 2003. Irrigation scheduling simulation: the model ISAREG. In Tools for Drought Mitigation in Mediterranean Regions, Rossi G, Cancelliere A, Pereira LS, Oweis T, Shatanawi M, Zairi A (eds). Kluwer: Dordrecht; 161-180.

Pereira LS, Dukhovny VA, Horst MG (eds). 2005. Irrigation Management for Combating Desertification in the Aral Sea Basin. Assessment and Tools. Vita Color Publisher: Tashkent.

Pereira LS, Gonçalves JM, Dong B, Mao Z, Fang SX. 2007. Assessing basin irrigation and scheduling strategies for saving irrigation water and controlling salinity in the Upper Yellow River Basin, China. Agricultural Water Management 93(3): 109-122.

Popova Z, Eneva S, Pereira LS. 2006. Model validation, crop coefficients and yield response factors for maize irrigation scheduling based on long-term experiments. Biosystems Engineering 95(1): 139-149.

Shreder VR, Vasiliev IK, Trunova TA. 1977. Hydromodule zoning and calculation of irrigation norms for cotton under arid conditions. In Design and Efficiency of Irrigation and Drainage System Performance in Central Asia, Vol. 8, Kadirov AA (ed.). SANIIRI: Tashkent; 28-41 (in Russian). 
Stewart JL, Hanks RJ, Danielson RE, Jackson EB, Pruitt WO, Franklin WT, Riley JP, Hagan RM. 1977. Optimizing Crop Production through Control of Water and Salinity Levels in the Soil. Utah Water Research Laboratory Report PRWG151-1, Utah State University, Logan.

Teixeira JL, Pereira LS. 1992. ISAREG, an irrigation scheduling model. ICID Bulletin 41(2): 29-48.

Victoria FB, Viegas Filho JS, Pereira LS, Teixeira JL, Lanna AE. 2005. Multi-scale modeling for water resources planning and management in rural basins. Agricultural Water Management 77: 4-20.

WWRP/WGNE. 2007. Forecast verification - issues, methods and FAQ. In Third International Workshop on Verification Methods (WMO/ WCRP/WWRP/COST and ECMWF, Reading, UK). WWRP/WGNE Joint Working Group on Verification, ECMWF (http://www.bom.gov.au/ bmrc/wefor/staff/eee/verif/verif_web_page.html).

Yazar A, Sezen SM, Sesveren S. 2002. LEPA and trickle irrigation of cotton in the Southeast Anatolia Project (GAP) area in Turkey. Agricultural Water Management 54(3): 189-203.

Zairi A, El Amami H, Slatni A, Pereira LS, Rodrigues PN, Machado T. 2003. Coping with drought: deficit irrigation strategies for cereals and field horticultural crops in Central Tunisia. In Tools for Drought Mitigation in Mediterranean Regions, Rossi G, Cancelliere A, Pereira LS, Oweis T, Shatanawi M, Zairi A (eds). Kluwer: Dordrecht; 181-201. 